\title{
Perbandingan Perolehan Daya Solar Panel Monocrystalline Terhadap Solar Panel Polycrystalline
}

\author{
Ervan Pratama $^{1 *}$ and Richa Watiasih ${ }^{2)}$ \\ ${ }^{1,2)}$ Program Studi Teknik Elektro, Universitas Bhayangkara Surabaya, Indonesia \\ Corresponding Email: *)erphandpratama@gmail.com
}

\begin{abstract}
The availability of two types of solar panels that are common in the market namely monocrystalline and polycrystalline types cause confusion in the selection so that many solar panel users are questioning the differences of these two types of solar panel. This study produced a data logger system using Arduino Uno R3 to control voltage, current and temperature sensors for logging data that stores power measurement data from monocrystalline and polycrystalline solar panel in a micro SD. After it we can manage data to compare power produced between two types the solar panel. From the results of testing this data logger system it can be seen that monocrystalline solar panel are $\mathbf{9 . 1 8 \%}$ better on power produced than polycrystalline when the maximum power conversion is generated.
\end{abstract}

Key words : Solar panel, Monocrystalline, Polycrystalline, Logging Data

\section{Pendahuluan}

Sinar matahari adalah sumber energi terbesar di bumi, dari keseluruhan energi yang dipancarkan berupa cahaya dan panas, hanya sebagaian kecil dari energi dari matahari yang sampai di permukaan bumi, namun energi yang kecil itu mampu untuk memenuhi kebutuhan energi di bumi [1][2].

Pemanfaatan potensi energi yang besar dari matahari sangat diperlukan sebagai alternatif dari sumber energi terbarukan sehingga tidak bergantung kepada sumber energi listrik yang berasal dari bahan bakar fosil yang ketersediaannya juga terbatas [3]. Pertumbuhan jumlah produksi solar panel di dunia terus meningkat dikarenakan perkembangan material dan alat pembuatnya yang juga semakin canggih [4].

Pemantauan daya keluaran dari solar panel sangat diperlukan agar dapat mengetahui dan menilai performa dari sebuah solar panel terhadap perubahan intensitas cahaya pada waktu-waktu tertentu [5]. Pemantauan dapat menggunakan perangkat lunak yang terhubung dengan pengendali alat pengukur sehingga dapat mengetahui hasil keluaran daya secara realtime/langsung tanpa perlu untuk melakukan pengukuran secara manual yang bersifat tidak langsung [6][7].

Penelitian ini mengusulkan sebuah sistem data logger yang bertujuan untuk mengetahui perbandingan performa daya yang dihasilkan dari solar panel jenis Monocrystalline dan jenis Polycrystalline. Sistem ini menggunakan mikrokontroler Arduino uno R3 untuk mengukur, mengakuisisi, menyimpan dan menampilkan hasil pengukuran performa solar panel sehingga didapatkan data pengukuran yang akurat dan dapat mengetahui performa dari solar panel Monocrystalline dan Polycrystalline.

\section{Metodologi}

\section{A. Perancangan Hardware}

Pada tahap ini dilakukan perancangan desain dari sistem perbandingan performa solar panel yang akan ditampilkan dalam bentuk diagram blok pada Gambar 1.

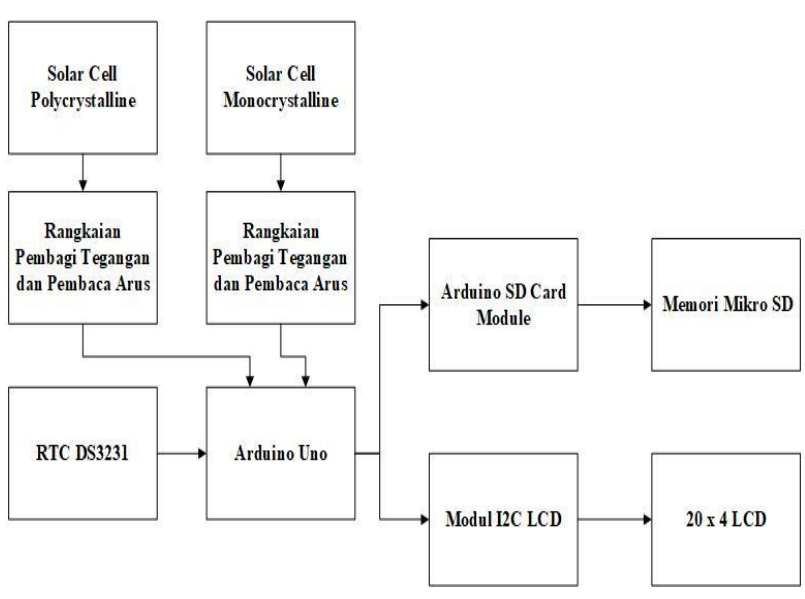

Gambar 1. Blok diagram hardware.

\section{Solar Panel Jenis Monocrystalline}

Dalam penelitian ini menggunakan solar panel jenis monocrystalline merk GH Solar dengan kapasitas daya sebesar 10Wp yang memiliki dimensi Panjang x Lebar x Tinggi $(350 \mathrm{~mm} \times 255 \mathrm{~mm} \times 17 \mathrm{~mm})$. Secara fisik ciri khusus dari solar panel ini adalah permukaan berwarna hitam seperti yang ditunjukkan pada Gambar 2.

\section{Solar Panel Jenis Polycrystalline}

Dalam penelitian ini menggunakan solar panel jenis polycrystalline merk YUNDE dengan kapasitas daya sebesar 10Wp yang memiliki dimensi Panjang $\mathrm{x}$ Lebar $\mathrm{x}$ Tinggi $(350 \mathrm{~mm} \times 235 \mathrm{~mm} \times 18 \mathrm{~mm})$. Secara fisik ciri 
khusus dari solar panel ini adalah permukaan berwarna biru tua seperti yang ditunjukkan pada Gambar 3.

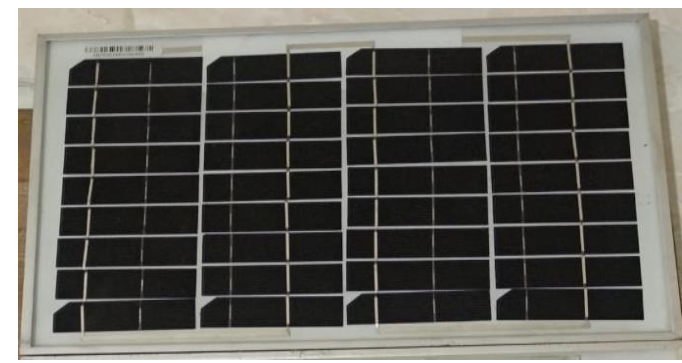

Gambar 2. Solar Panel jenis Monocrystalline.

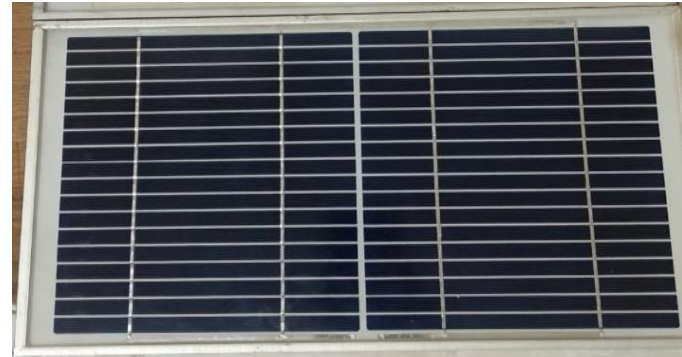

Gambar 3. Solar Panel jenis Polycrystalline.

\section{Rangkaian Pembagi Tegangan dan Pembaca Arus}

Rangkaian pembagi tegangan dan pembaca arus yang digunakan memiliki spesifikasi maksimal 24V DC dan 1A. Rangkaian ini berupa penguat sinyal analog dengan menggunakan Op-Amp LM358 mode non-inverting. Pada rangkaian ini terdapat sebuah resistor shunt dengan nilai $0.22 \Omega / 2$ Watt. Desain rangkaiannya dapat dilihat pada Gambar 4.

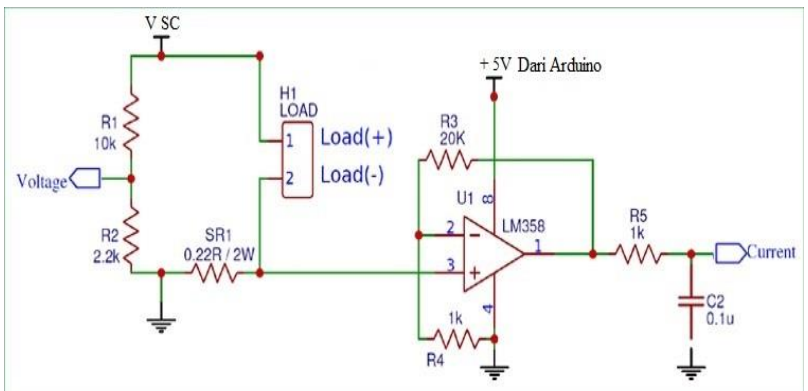

Gambar 4. Skema Rangkaian Pembagi Tegangan dan Pembaca Arus.

Rangkaian ini memiliki gain sebesar 21x dengan cara mengukur besaran gain ditunjukkan pada persamaan (1).

$$
\text { Gain }=\frac{V_{\text {out }}}{V_{\text {in }}}=1+\left(\frac{R_{3}}{R_{4}}\right)
$$

Dengan tegangan drop pada resistor shunt adalah maksimal sebesar $0.2 \mathrm{~V}$, maka Nilai tegangan $0.2 \mathrm{~V}$ merupakan nilai ketetapan dari rangkaian karena tegangan output maksimum pada pin 1 dari $O P-A M P$ yang di desain dengan gain $21 \mathrm{x}$ sehingga menghasilkan tegangan sebesar $4.2 \mathrm{~V}$ dan nilai tersebut sudah hampir melebihi batas tegangan masukan pada pin analog Arduino. Kemampuan pembacaan arus pada rangkaian ini adalah sebesar maksimum 1A, maka jika ingin membuat rangkaian dengan pembacaan arus yang lebih tinggi dapat digunakan hukum ohm untuk menentukan nilai resistor shunt yang digunakan

\section{RTC DS3231}

RTC (Real Time Clock) yang digunakan merupakan perangkat yang memberikan informasi waktu dan tanggal pada sistem. Selain dari fungsi waktu dan tanggal, modul ini juga sudah dilengkapi oleh termometer sehingga sudah langsung dapat memberikan informasi suhu terkini tanpa perlu dilakukan kalibrasi. Modul ini yang membuat penyimpanan data dapat dibagi berdasarkan waktu dan pemisahan file logging berdasarkan tanggal. Bentuk fisik Modul RTC ditunjukkan pada Gambar 5.

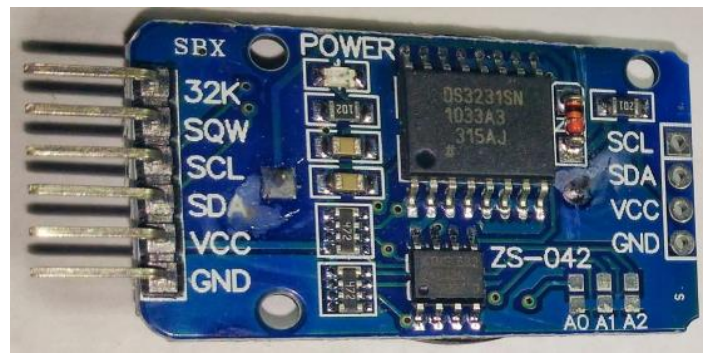

Gambar 5. RTC DS3231.

Modul memiliki IC EEPROM tipe AT24C32 dengan 32K EEPROM yang dapat dimanfaatkan untuk menyimpan data. Interface atau antarmuka untuk mengakses modul ini yaitu menggunakan i2c atau two wire (SDA dan SCL). Sehingga apabila diakses menggunakan mikrokontroler misal Arduino Uno pin yang dibutuhkan 2 pin untuk data dan 2 pin untuk tegangan.

Modul DS3231 RTC ini pada umumnya sudah tersedia dengan baterai CR2032 yang berfungsi sebagai back up RTC apabila catu daya utama mati. RTC DS3231 memiliki rentang tegangan masukan antara $2.3 \mathrm{~V}$ sampai 5.5V. DS3231 memiliki kristal terintegrasi, sensor suhu, 2 alarm waktu terprogram, pin output $32.768 \mathrm{kHz}$ untuk memastikan akurasi yang lebih tinggi[9].

\section{Arduino Uno R3}

Arduino Uno R3 merupakan pusat pengolahan data dan semua informasi dari keseluruhan sistem. Arduino Uno R3 berbasis pada mikrokontroller Atmega 328 yang memiliki 6 pin analog dan 12 pin digital I/O. Dalam sistem ini Arduino Uno R3 mendapatkan daya dari sebuah catu daya $9 \mathrm{~V}$ untuk meminimalisir panas yang dihasilkan oleh regulator tegangan input dari konektor Jack DC saat perangkat beroperasional. Dari catu daya tersebut, Arduino juga memberikan catu daya sebesar $5 \mathrm{~V}$ ke rangkaian detektor arus, LCD dan Modul Mikro SD. Arduino Uno R3 yang digunakan dapat dilihat pada Gambar 6. 


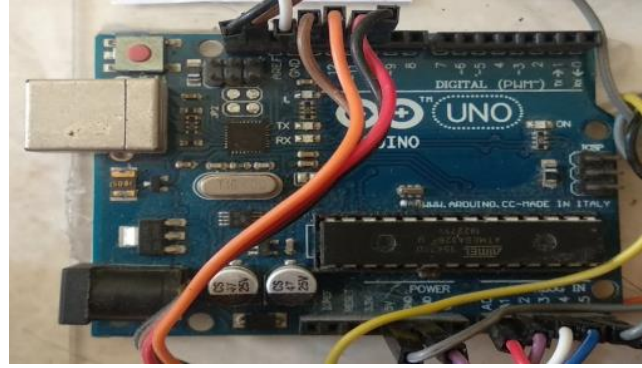

Gambar 6. Arduino Uno R3.

\section{Arduino SD Card Module}

Modul ini merupakan modul yang memiliki kemampuan baca dan tulis pada media penyimpanan berjenis mikro SD, namun dalam penelitian ini hanya fitur tulis yang digunakan. Digunakan mikro SD karena keandalan dan ketersedian dari memori mikro SD yang banyak serta dapat dengan mudah dibaca pada berbagai macam platform lainnya. Arduino SD Card Module mendukung kapasitas mikro SD hingga 32GB dan menggunakan protokol SPI (Serial Peripheral Interface) sebagai interkoneksi dengan Arduino. Bentuk Arduino SD Card Module ditunjukkan pada Gambar 7.

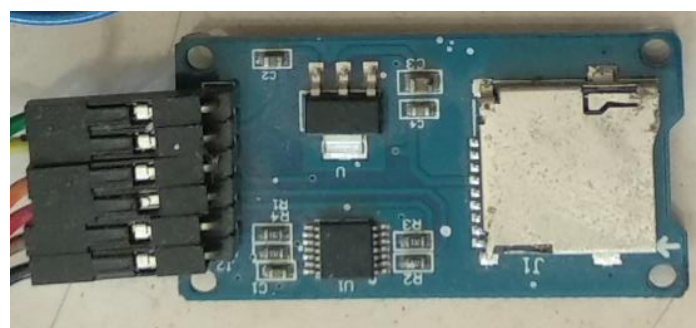

Gambar 7. Arduino SD Card Module.

\section{Modul I2C LCD}

Modul I2C LCD merupakan sebuah modul pendukung untuk mempermudah dan meminimalisir kebutuhan sambungan antara Arduino dengan LCD. Jika menggunakan hubungan langsung dengan LCD, dibutuhkan setidaknya 8 sambungan. Akan tetapi jika menggunakan Modul I2C maka sambungan hanya memerlukan 4 kabel saja yaitu 2 kabel sebagai data dan 2 kabel sebagai catu daya, sehingga sistem dapat lebih rapi dan ringkas dalam hal penggunaan kabel. Modul I2C LCD dapat dilihat pada Gambar 8 berikut.



Gambar 8. Modul I2C LCD.

\section{Memori Mikro SD}

Memori mikro SD yang digunakan dalam pengujian ini adalah Sandisk Ultra berkapasitas 32GB yang ditunjukkan pada Gambar 9. Memori ini memiliki format disk FAT32, kapasitas ini merupakan kapasitas maksimal yang dapat didukung dan dibaca oleh Arduino SD Card Module.



Gambar 9. Sandisk Ultra 32GB.

\section{LCD 20x4}

LCD 20x4 yang ditunjukkan pada Gambar 10 merupakan sebuah komponen pelengkap dalam pengujian, saat dibutuhkan pengamatan langsung untuk kondisi tegangan, arus, daya, suhu, waktu dan tanggal pengukuran serta kondisi mikro SD apakah normal atau tidak. Semua informasi ini dapat ditampilkan secara langsung dalam satu waktu dan hasil nilai pengukuran yang telah didapatkan dan diolah oleh Arduino akan ditampilkan pada LCD dan dimuat ulang/diperbarui setiap 1 menit sekali.



Gambar 10. LCD 20x4

\section{Dekko FT-7965}

Dekko FT-7965 merupakan kit alat ukur yang memiliki 5 macam kemampuan pengukuran. Parameter yang dapat diukur oleh alat ini adalah pengukuran cahaya, tingkat suara, kelembapan, suhu dan kecepatan angin. Memiliki LCD yang besar dengan kemampuan untuk data hold dan max hold untuk kemudahan dalam memantau parameter maksimal yang terukur. Dalam penelitian ini, pengukuran yang dilakukan dengan Dekko FT-7965 adalah pengukuran cahaya dengan satuan Lux. Perangkat ini memiliki bentuk fisik seperti pada Gambar 11.

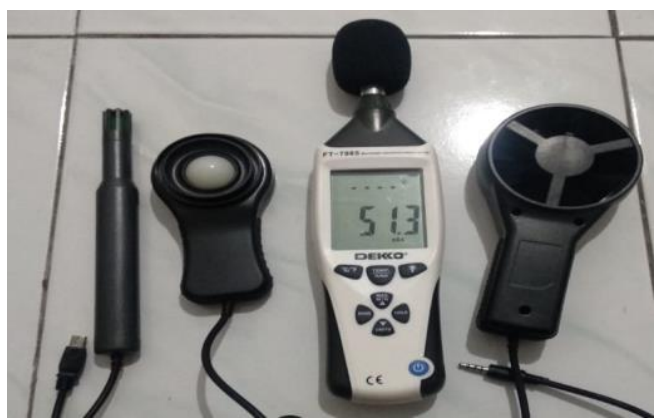

Gambar 11. Dekko FT-7965. 


\section{B. Perancangan Software}

Perancangan software dari sistem data logger ini akan ditampilkan dan dijelaskan pada flowchart yang ditunjukkan pada Gambar 12.

Berdasarkan Gambar 12. ditunjukkan beberapa blok logika urutan program. Pertama kali dimulai dengan inisialisasi perangkat yang terhubung pada Arduino yaitu Modul Mikro SD, LCD yang terhubung dengan I2C LCD dan RTC DS3231 sehingga Arduino mengenali masingmasing alamat dari perangkat dan dapat berjalan pada proses berikutnya yaitu dengan mengambil data tanggal, waktu, suhu dari RTC DS3231 melalui protokol komunikasi I2C melalui pin SDA dan SCL. Setelah itu sistem membaca data dari input analog yaitu data tegangan dan arus yang berasal dari rangkaian pembagi tegangan dan pembaca arus yang terhubung pada dua jenis solar panel yang berbeda. Setelah didapatkan data tegangan dan arus, mikrokontroller mengkalikan antara tegangan dan arus kemudian didapatkan satu besaran lain yaitu daya. Semua data disimpan di RAM (Random Access Memory) mikrokontroller dalam bentuk data float.

Sistem akan mendeteksi apakah terdapat memori mikro SD terpasang pada $S D$ Card Module atau tidak, apabila terdeteksi dan memori mikro SD dalam kondisi normal maka data float yang tersimpan pada RAM akan ditampilkan ke LCD dan juga ditulis ke memori mikro SD dalam format file csv. Masing-masing data akan ditulis ke file csv dengan dipisahkan berdasarkan waktu data tersebut didapat. Keseluruhan sistem akan mengulang siklus yang sama setiap 60 detik sekali. Namun apabila memori mikro SD tidak terdeteksi/rusak, maka sistem akan menampilkan tulisan "WRITE TO CARD ERROR" dan sistem akan berhenti beroperasional. Untuk dapat menggunakan sistem kembali, masukkan memori mikro SD yang normal, kemudian restart keseluruhan sistem.

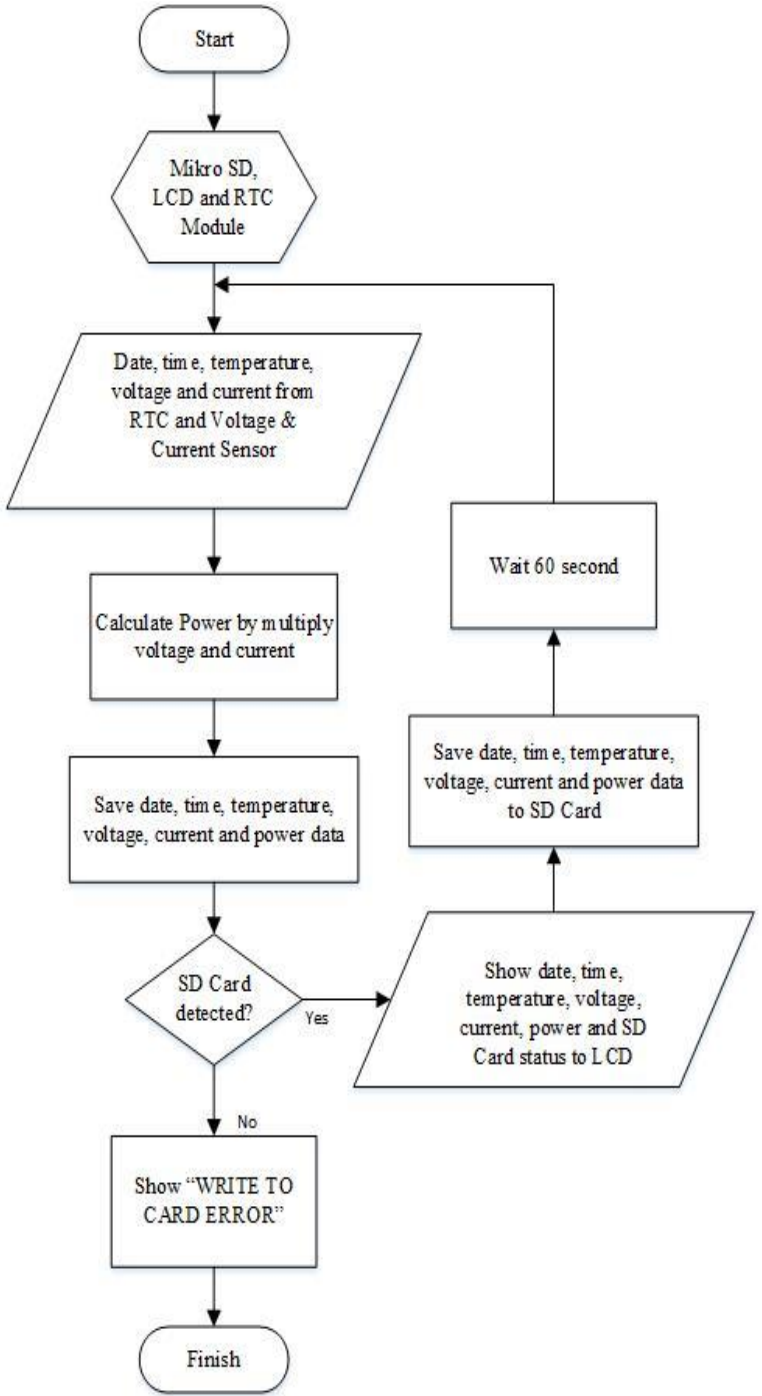

Gambar 12. Flowchart sistem.

\section{HaSil dan Pembahasan}

\section{A. Kalibrasi Perangkat}

Pada bab ini peralatan dilakukan kalibrasi terlebih dahulu untuk mengetahui persentase kesalahan sistem dibandingkan dengan AVOmeter Panelkit CK9205D. Sumber tegangan yang digunakan adalah baterai lithium yang dirangkai seri sehingga mampu menghasilkan beberapa variasi tegangan tergantung dari titik pengukuran. Kesalahan persentase pengukuran dihitung menggunakan persamaan 2.

$\%$ Kesalahan $=\frac{\text { nilai AVOmeter-nilai Pengukuran }}{\text { nilai } \text { AVOmeter }} X 100$

Dari hasil pengukuran kemudian di rata-rata untuk mengetahui persentase kesalahan pengukuran pada alat ukur yang digunakan. Proses kalibrasi dapat dilihat pada Gambar 13 berikut. 


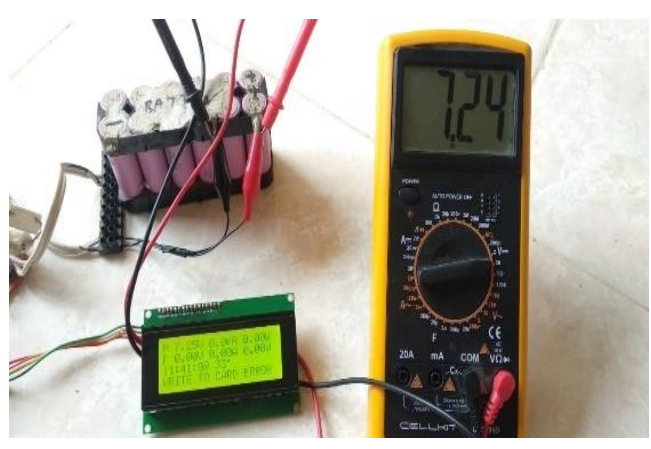

Gambar 13. Proses kalibrasi tegangan dan arus.

\section{Hasil Kalibrasi Pengukuran Tegangan}

Pengukuran dari 2 detektor tegangan yang dilakukan proses kalibrasi untuk mendapatkan hasil pengukuran yang benar ketika dibandingkan pengukuran menggunakan AVO meter Panelkit CK9205D sebagai acuan.

Tabel 1. Data Pembacaan Kalibrasi Tegangan.

\begin{tabular}{ccccc}
\hline AVOMETER & $\begin{array}{c}\text { Detektor } \\
\text { V1 }\end{array}$ & $\begin{array}{c}\text { Persentase } \\
\text { Kesalahan }\end{array}$ & $\begin{array}{c}\text { Detektor } \\
\text { V2 }\end{array}$ & $\begin{array}{c}\text { Persentase } \\
\text { Kesalahan }\end{array}$ \\
\hline $3,57 \mathrm{~V}$ & $3,58 \mathrm{~V}$ & $0,28 \%$ & $3,56 \mathrm{~V}$ & $0,28 \%$ \\
\hline $7,26 \mathrm{~V}$ & $7,3 \mathrm{~V}$ & $0,55 \%$ & $7,25 \mathrm{~V}$ & $0,14 \%$ \\
\hline $11,26 \mathrm{~V}$ & $11,3 \mathrm{~V}$ & $0,36 \%$ & $11,3 \mathrm{~V}$ & $0,36 \%$ \\
\hline $14,92 \mathrm{~V}$ & $14,9 \mathrm{~V}$ & $0,13 \%$ & $14,9 \mathrm{~V}$ & $0,13 \%$ \\
\hline $18,46 \mathrm{~V}$ & $18,6 \mathrm{~V}$ & $0,76 \%$ & $18,6 \mathrm{~V}$ & $0,76 \%$ \\
\hline
\end{tabular}

Dari hasil pengukuran tegangan yang ditunjukkan pada Tabel 1 dapat diketahui bahwa persentase kesalahan pengukuran yang terjadi pada detektor tegangan sangat kecil yaitu dibawah 1\%. Apabila dihitung rata-rata kesalahan pengukuran dari alat detektor tegangan yang di rakit ini adalah sebesar $0,36 \%$ pada detektor tegangan $\mathrm{V} 1$ yang digunakan untuk mengukur solar panel Monocrystalline dan rata-rata persentase kesalahan sebesar $0.11 \%$ pada detektor tegangan V2 yang digunakan untuk mengkur solar panel Polycrystalline.

\section{Hasil Kalibrasi Pengukuran Arus}

Berikut adalah hasil pengukuran dari 2 detektor arus yang dilakukan proses kalibrasi pada masing-masing blok untuk mendapatkan hasil pengukuran yang benar ketika dibandingkan pengukuran menggunakan AVOmeter Panelkit CK9205D sebagai acuan.

Tabel 2 Data Pembacaan Kalibrasi Arus.

\begin{tabular}{ccccc}
\hline AVOMETER & $\begin{array}{c}\text { Detekto } \\
\mathbf{A 1}\end{array}$ & $\begin{array}{c}\text { Persentase } \\
\text { Kesalahan }\end{array}$ & $\begin{array}{c}\text { Detektor } \\
\mathbf{A 2}\end{array}$ & $\begin{array}{c}\text { Persentase } \\
\text { Kesalahan }\end{array}$ \\
\hline $0,23 \mathrm{~A}$ & $0,23 \mathrm{~A}$ & $0 \%$ & $0,23 \mathrm{~A}$ & $0 \%$ \\
\hline $0,36 \mathrm{~A}$ & $0,36 \mathrm{~A}$ & $0 \%$ & $0,36 \mathrm{~A}$ & $0 \%$ \\
\hline $0,47 \mathrm{~A}$ & $0,46 \mathrm{~A}$ & $2.13 \%$ & $0,47 \mathrm{~A}$ & $2.13 \%$ \\
\hline $0,59 \mathrm{~A}$ & $0,59 \mathrm{~A}$ & $0 \%$ & $0,58 \mathrm{~A}$ & $1.69 \%$ \\
\hline $0,71 \mathrm{~A}$ & $0,71 \mathrm{~A}$ & $0 \%$ & $0,71 \mathrm{~A}$ & $0 \%$ \\
\hline
\end{tabular}

Dari hasil pengukuran arus yang ditunjukkan pada Tabel 2 dapat diketahui bahwa persentase kesalahan pengukuran yang terjadi pada detektor arus cukup kecil yaitu sekitar $2 \%$ pada salah satu titik pengukuran. Dan apabila dihitung rata-rata kesalahan pengukuran dari alat detektor arus yang di rakit ini adalah sebesar $0,43 \%$ pada detektor arus A1 yang digunakan untuk mengukur Solar Panel Monocrystalline dan rata-rata persentase kesalahan sebesar $0.76 \%$ pada detektor arus A2 yang digunakan untuk mengkur Solar Panel Polycrystalline.

\section{B. Hasil Pengujian Sistem}

Dalam pengujian sistem menyajikan data pengujian dan pengukuran setelah dilakukan kalibrasi ketepatan angka pengukuran pada sistem dibandingkan dengan pengukuran menggunakan alat ukur pada kondisi tegangan dan arus yang berbeda-beda. Kondisi pada saat dilakukan pengukuran untuk mendapat data pada penelitian ini ditunjukkan pada Gambar 14.



Gambar 14. Pengujian sistem.

Pada Gambar 14 menunjukkan beberapa hardware pada saat melakukan pengujian sistem. Adapun masingmasing hardware adalah sebagai berikut:

1. Solar Panel Monocrystalline 10Wp.

2. Solar Panel Polycrystalline 10Wp.

3. Dekko FT-7965 untuk mengukur Lux Cahaya.

4. DS3231 sebagai RTC dan Thermometer.

5. LCD untuk menampilkan pengukuran terkini.

Hasil dari rata-rata pengukuran yang dilakukan selama 14 hari yaitu pada tanggal 17-11-2019 hingga 30-11-2019. Hasil pengukuran yang ditampilkan adalah pengukuran daya masing-masing dari solar panel dan suhu permukaan solar panel. Tabel 3 menunjukkan hasil rata-rata pengukuran masing-masing solar panel.

Tabel 3. Data rata-rata Pengukuran Solar Panel Selama 14 Hari Pengamatan.

\begin{tabular}{cccccccc}
\hline Waktu & \multicolumn{3}{c}{ Monocrystalline } & \multicolumn{3}{c}{ Polycrystalline } & \multirow{2}{*}{$\begin{array}{c}\text { Suhu } \\
\end{array}$} \\
\cline { 2 - 7 } & $\begin{array}{c}\text { Tegangan } \\
\text { (V) }\end{array}$ & $\begin{array}{c}\text { Arus } \\
(\mathrm{A})\end{array}$ & $\begin{array}{l}\text { Daya } \\
(\mathrm{W})\end{array}$ & $\begin{array}{c}\text { Tegangan } \\
(\mathrm{V})\end{array}$ & $\begin{array}{l}\text { Arus } \\
(\mathrm{A})\end{array}$ & $\begin{array}{l}\text { Daya } \\
(\mathrm{W})\end{array}$ \\
\hline $8: 00$ & 9.55 & 0.32 & 3.09 & 9.54 & 0.32 & 3.10 & 45.83 \\
\hline $8: 10$ & 10.54 & 0.36 & 3.76 & 10.53 & 0.36 & 3.77 & 46.90 \\
\hline $8: 20$ & 10.75 & 0.36 & 3.92 & 10.71 & 0.36 & 3.90 & 48.11 \\
\hline $8: 30$ & 11.47 & 0.39 & 4.46 & 11.43 & 0.39 & 4.45 & 48.89 \\
\hline $8: 40$ & 12.38 & 0.42 & 5.20 & 12.33 & 0.42 & 5.18 & 49.85 \\
\hline $8: 50$ & 12.47 & 0.42 & 5.28 & 12.39 & 0.42 & 5.23 & 47.54 \\
\hline $9: 00$ & 12.90 & 0.44 & 5.65 & 12.76 & 0.43 & 5.55 & 51.54 \\
\hline $9: 10$ & 13.89 & 0.47 & 6.57 & 13.70 & 0.47 & 6.40 & 52.18 \\
\hline
\end{tabular}




\begin{tabular}{|c|c|c|c|c|c|c|c|}
\hline $9: 20$ & 14.20 & 0.48 & 6.87 & 13.95 & 0.48 & 6.63 & 53.15 \\
\hline $9: 30$ & 14.64 & 0.50 & 7.30 & 14.33 & 0.49 & 7.01 & 53.87 \\
\hline 9:40 & 14.49 & 0.49 & 7.14 & 14.15 & 0.48 & 6.83 & 54.49 \\
\hline $9: 50$ & 14.42 & 0.49 & 7.08 & 13.91 & 0.47 & 6.60 & 54.98 \\
\hline 10:00 & 15.19 & 0.52 & 7.87 & 14.73 & 0.50 & 7.39 & 55.49 \\
\hline $10: 10$ & 15.37 & 0.52 & 8.05 & 14.85 & 0.51 & 7.52 & 56.19 \\
\hline $10: 20$ & 14.63 & 0.50 & 7.29 & 14.11 & 0.48 & 6.78 & 56.69 \\
\hline $10: 30$ & 14.34 & 0.49 & 7.01 & 13.82 & 0.47 & 6.51 & 56.46 \\
\hline $10: 40$ & 14.71 & 0.50 & 7.37 & 14.15 & 0.48 & 6.84 & 56.32 \\
\hline $10: 50$ & 14.80 & 0.50 & 7.46 & 14.21 & 0.48 & 6.88 & 56.42 \\
\hline 11:00 & 15.05 & 0.51 & 7.72 & 14.42 & 0.49 & 7.10 & 56.49 \\
\hline 11:10 & 15.32 & 0.52 & 8.00 & 14.67 & 0.50 & 7.34 & 56.74 \\
\hline 11:20 & 15.40 & 0.52 & 8.07 & 14.71 & 0.50 & 7.39 & 57.00 \\
\hline 11:30 & 15.68 & 0.53 & 8.38 & 14.97 & 0.51 & 7.64 & 57.20 \\
\hline 11:40 & 15.90 & 0.54 & 8.62 & 15.16 & 0.52 & 7.85 & 57.64 \\
\hline $11: 50$ & 16.01 & 0.55 & 8.74 & 15.25 & 0.52 & 7.94 & 58.06 \\
\hline 12:00 & 15.93 & 0.54 & 8.66 & 15.17 & 0.52 & 7.85 & 58.36 \\
\hline 12:10 & 15.97 & 0.54 & 8.70 & 15.18 & 0.52 & 7.87 & 58.51 \\
\hline $12: 20$ & 15.85 & 0.54 & 8.56 & 15.06 & 0.51 & 7.74 & 58.56 \\
\hline $12: 30$ & 15.78 & 0.54 & 8.49 & 14.98 & 0.51 & 7.65 & 58.36 \\
\hline $12: 40$ & 15.75 & 0.54 & 8.44 & 14.93 & 0.51 & 7.61 & 58.03 \\
\hline $12: 50$ & 15.72 & 0.53 & 8.41 & 14.89 & 0.51 & 7.56 & 57.76 \\
\hline 13:00 & 15.64 & 0.53 & 8.33 & 14.79 & 0.50 & 7.46 & 57.38 \\
\hline 13:10 & 15.39 & 0.52 & 8.05 & 14.52 & 0.50 & 7.19 & 57.09 \\
\hline $13: 20$ & 15.04 & 0.51 & 7.71 & 14.16 & 0.48 & 6.84 & 56.76 \\
\hline 13:30 & 14.75 & 0.50 & 7.40 & 13.85 & 0.47 & 6.54 & 56.18 \\
\hline $13: 40$ & 14.57 & 0.50 & 7.22 & 13.65 & 0.47 & 6.36 & 55.61 \\
\hline $13: 50$ & 14.12 & 0.48 & 6.80 & 13.19 & 0.45 & 5.94 & 55.09 \\
\hline 14:00 & 13.81 & 0.47 & 6.49 & 12.84 & 0.44 & 5.62 & 54.15 \\
\hline $14: 10$ & 12.96 & 0.44 & 5.72 & 12.00 & 0.41 & 4.91 & 53.42 \\
\hline $14: 20$ & 12.40 & 0.42 & 5.23 & 11.39 & 0.39 & 4.43 & 52.52 \\
\hline 14:30 & 12.13 & 0.41 & 5.01 & 11.06 & 0.38 & 4.17 & 51.58 \\
\hline 14:40 & 11.89 & 0.40 & 4.79 & 10.74 & 0.37 & 3.94 & 50.81 \\
\hline 14:50 & 11.36 & 0.39 & 4.39 & 10.18 & 0.35 & 3.53 & 50.14 \\
\hline 15:00 & 10.75 & 0.36 & 3.92 & 9.56 & 0.33 & 3.11 & 49.45 \\
\hline $15: 10$ & 10.09 & 0.34 & 3.45 & 8.89 & 0.30 & 2.70 & 48.55 \\
\hline $15: 20$ & 9.24 & 0.31 & 2.90 & 8.06 & 0.27 & 2.22 & 47.74 \\
\hline $15: 30$ & 8.38 & 0.28 & 2.37 & 7.23 & 0.25 & 1.78 & 46.76 \\
\hline $15: 40$ & 7.65 & 0.26 & 1.98 & 6.55 & 0.22 & 1.46 & 45.76 \\
\hline $15: 50$ & 6.40 & 0.22 & 1.39 & 5.44 & 0.19 & 1.01 & 44.69 \\
\hline 16:00 & 5.21 & 0.18 & 0.92 & 4.40 & 0.15 & 0.66 & 43.42 \\
\hline $16: 10$ & 4.22 & 0.14 & 0.60 & 3.54 & 0.12 & 0.43 & 42.12 \\
\hline $16: 20$ & 3.38 & 0.11 & 0.39 & 2.82 & 0.10 & 0.27 & 40.75 \\
\hline $16: 30$ & 2.71 & 0.09 & 0.25 & 2.24 & 0.08 & 0.17 & 39.37 \\
\hline $16: 40$ & 1.97 & 0.07 & 0.13 & 1.63 & 0.06 & 0.09 & 38.21 \\
\hline $16: 50$ & 1.23 & 0.04 & 0.05 & 1.03 & 0.04 & 0.04 & 37.04 \\
\hline 17:00 & 0.67 & 0.02 & 0.02 & 0.57 & 0.02 & 0.01 & 35.98 \\
\hline
\end{tabular}

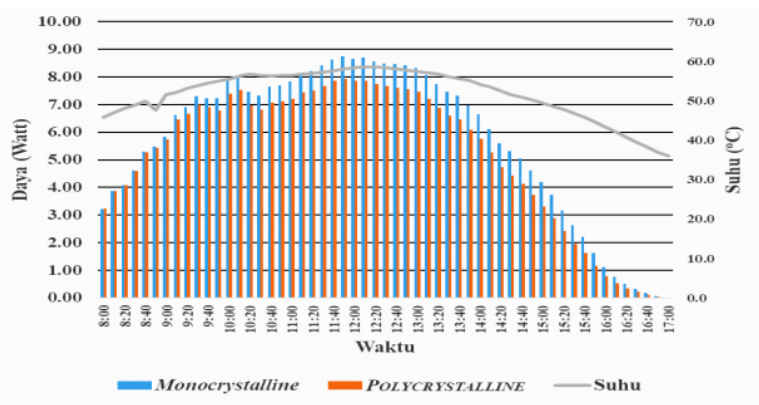

Gambar 15. Grafik Rata-Rata Pengukuran Daya terhadap Suhu.
Berdasarkan Gambar 15 yang merupakan grafik ratarata dari keseluruhan pengukuran, dapat dilihat bahwa dalam semua hasil menunjukkan bahwa solar panel monocrystalline menghasilkan daya yang selalu lebih besar dibandingkan dengan solar panel polycrystalline. Dengan daya pengukuran maksimum pada $8.74 \mathrm{~W}$ untuk monocrystalline dan $7.94 \mathrm{~W}$ untuk polycrystalline pada pukul $11: 50$ pada suhu $58.1^{\circ} \mathrm{C}$. Hasil pengukuran daya terendah yaitu sebesar $0.02 \mathrm{~W}$ untuk monocrystalline dan 0.01W untuk polycrystalline pada pukul 17:00 dan suhu terukur adalah $36^{\circ} \mathrm{C}$. Selain daripada itu kondisi antara daya yang dihasilkan dengan suhu juga selalu sebanding sekalipun tidak dalam satu titik yang sama perubahannya karena suhu membutuhkan waktu untuk berubah nilai, sedangkan daya dapat langsung berubah mengikuti intensitas cahaya matahari.

Pada Gambar 16 ditampilkan rata-rata hasil pengukuran pengaruh intensitas cahaya matahari yang diukur menggunakan Dekko FT-7965 dibandingkan dengan jumlah daya yang dihasilkan oleh solar panel.

Berdasarkan Gambar 16 yang menampilkan hasil ratarata pengukuran yang dilakukan selama 7 hari, semua hasil menunjukkan bahwa intensitas cahaya berpengaruh terhadap jumlah daya yang dikeluarkan oleh solar panel. Dengan hasil pengukuran tertinggi yang didapat adalah $6.05 \mathrm{~W}$ untuk monocrystalline dan $5.31 \mathrm{~W}$ untuk polycrystalline pada pukul 13:00 dan pada intensitas cahaya matahari sebesar 64.17 kLux. Kemudian hasil pengukuran terendah adalah $0.03 \mathrm{~W}$ untuk monocrystalline dan $0.02 \mathrm{~W}$ untuk polycrystalline pada pukul 17:00 pada intensitas cahaya 0.41 kLux. Ketika intensitas cahaya tinggi maka permukaan panel juga mendapatkan radiasi matahari yang tinggi pula, namun ketika intensitas cahaya rendah maka radiasi yang diterima oleh solar panel juga lebih sedikit sehingga berpengaruh pada daya keluarannya.

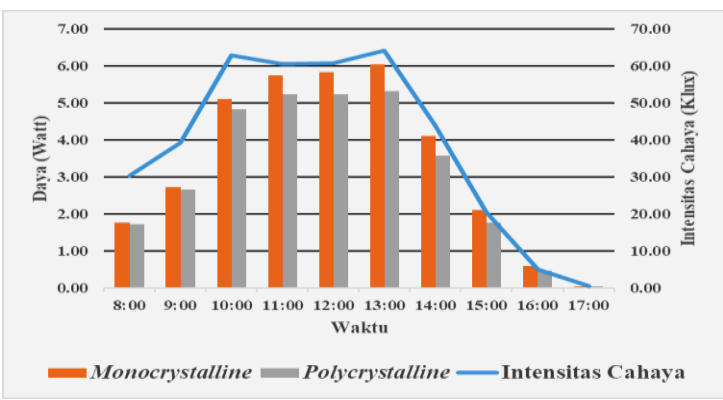

Gambar 16. Grafik Rata-Rata Pengukuran Daya terhadap Intensitas Cahaya.

Pada Tabel 4 ditampilkan hasil dari pengamatan dan pengukuran dalam beberapa kondisi pencahayaan dan penyinaran yang berbeda. Kondisi pengukuran dimaksudkan untuk membandingkan respon dari kedua jenis solar panel yang diuji, sehingga dapat diketahui perbedaan performa dari masing-masing jenis. 
Tabel 4. Pengukuran Solar Panel Dalam Beberapa Kondisi.

\begin{tabular}{|c|c|c|c|c|c|c|c|c|}
\hline \multirow{2}{*}{ Kondisi } & \multicolumn{3}{|c|}{ Monocrystalline } & \multicolumn{3}{|c|}{ Polycrytalline } & \multirow{2}{*}{$\begin{array}{c}\text { Intensitas } \\
\text { Cahaya }\end{array}$} & \multirow{2}{*}{$\begin{array}{l}\text { Persentase } \\
\text { Selisih } \\
\text { Daya }\end{array}$} \\
\hline & Tegangan & Arus & Daya & Tegangan & Arus & Daya & & \\
\hline $\begin{array}{c}\text { Normal } \\
\text { Cerah }\end{array}$ & $14.6 \mathrm{~V}$ & $0.51 \mathrm{~A}$ & $7.27 \mathrm{~W}$ & $14 \mathrm{~V}$ & $0.48 \mathrm{~A}$ & $6.79 \mathrm{~W}$ & 80Klux & $6.60 \%$ \\
\hline $\begin{array}{c}\text { Tertutup } \\
\text { bayang- } \\
\text { bayang } \\
\text { samar }\end{array}$ & $7.03 \mathrm{~V}$ & $0.24 \mathrm{~A}$ & $1.68 \mathrm{~W}$ & $6.22 \mathrm{~V}$ & $0.21 \mathrm{~A}$ & $1.33 \mathrm{~W}$ & 19.8Klux & $20.83 \%$ \\
\hline $\begin{array}{c}\text { Tertutup } \\
\text { Daun- }\end{array}$ & $8.82 \mathrm{~V}$ & $0.3 \mathrm{~A}$ & $2.63 \mathrm{~W}$ & $7.94 \mathrm{~V}$ & $0.27 \mathrm{~A}$ & $2.17 \mathrm{~W}$ & 80Klux & $17.49 \%$ \\
\hline
\end{tabular}

Berdasarkan Tabel 4 yang menunjukan pengukuran daya keluaran dari kedua solar panel yang dikondisikan dalam beberapa kondisi yaitu normal, tertutup bayangbayang dan tertutup objek berupa daun-daun. Dari hasil pengamatan dan pengukuran yang dilakukan menunjukan hasil daya keluaran solar panel monocrystalline sebesar $7.27 \mathrm{~W}$ dan $6.79 \mathrm{~W}$ untuk polycrystalline dengan besar intensitas cahaya matahari sebesar $80 \mathrm{kLux}$.

Pengukuran yang dilakukan dengan memberikan penghalang samar berupa kain transparant di atas permukaan panel, dan menghasilkan pengukuran daya sebesar $1.68 \mathrm{~W}$ untuk monocrystalline dan $1.33 \mathrm{~W}$ untuk polycrystalline, dengan besar intensitas cahaya matahari adalah sebesar $19.8 \mathrm{kLux}$.

Pengukuran yang dilakukan dengan memberikan daun-daun di permukaan solar panel, hal ini sering terjadi pada solar panel yang terpasang di dekat pepohonan seperti yang ada di jalan-jalan di kota Surabaya. Besar intensitas cahaya yang terukur pada simulasi ini adalah sebesar 80 kLux. Akan tetapi besar daya yang dikeluarkan oleh kedua solar panel turun drastis jika dibandingkan dengan pengukuran pada baris pertama dengan intensitas cahaya yang sama, angka pengukuran daya terukur sebesar $2.63 \mathrm{~W}$ untuk monocrystalline dan $2.17 \mathrm{~W}$ untuk polycrystalline. Hal ini terjadi karena daun-daun menutup permukaan panel dengan sempurna dan hanya menyisakan beberapa bagian permukaan yang terpapar oleh cahaya matahari, sehingga besar daya yang dikeluarkan juga turun secara drastis karena fenomena ini.

\section{KeSIMPUlaN}

Dengan spesifikasi dan kondisi penyinaran yang sama, solar panel jenis monocrystalline dapat menghasilkan daya yang lebih banyak jika dibandingkan dengan solar panel jenis polycrystalline. Karena sifat ini, maka di luas area yang sama sistem monocrystalline memiliki rating daya yang lebih besar dibandingkan jenis polycrystalline.

Suhu dan intensitas cahaya yang mengenai permukaan dari solar panel sangatlah berpengaruh terhadap performa solar panel, sehingga penempatan dari solar panel juga perlu diperhatikan agar mendapatkan hasil yang maksimal. Dari hasil pengamatan, rata-rata selisih daya yang dihasilkan antara solar panel monocrystalline dan polycrystalline dari pengukuran maksimum yang dilakukan selama 14 hari adalah sebesar 9.18\%. Dengan panel berjenis monocrystalline memiliki kemampuan menghasilkan daya yang lebih bagus dibandingkan dengan panel berjenis polycrystalline.

\section{UCAPAN TERIMA KASIH}

Kami mengucapkan banyak terima kasih atas bantuan dari para tenaga pengajar Teknik Elektro Universitas Bhayangkara Surabaya terutama untuk Pembimbing sehingga penelitian ini dapat terselesaikan.

\section{Daftar Pustaka}

[1] N.A. Handayani dan D. Ariyanti, "Potency Solar Energy Application in Indonesia", Int. Journal of Renewable Energy Development (IJRED), pp. 33-38, 2012.

[2] S. Sharma, K. K. Jain, dan A. Sharma, "Solar Panels: In Research and Applications-A Review", Materials Sciences and Applications, Vol. 6, 1145-1155, 2015,

[3] N. Pasaribu, Rusdianasari, dan A. Syarif, "Efficiency of $9 K W p$ Sun Tracking Photovoltaic in Palembang, Indonesia", $6^{\text {th }}$ International Conference on Sustainable Agriculture, Food and EnergyI (OP Conference Series: Earth and Environmental Science 347), pp.1-6, 2019.

[4] L.A. Dobrzański, A. Drygała, M. Giedroć, dan M. Macek, "Monocrystalline Silicon Solar Panels Applied in Photovoltaic System", Journal of Achievements in Materials and Manufacturing Engineering, vol. 53, no. 1, pp. 7-13, 2012.

[5] A. Tasçioglu, O. Taskin, dan A. Vardar, "A Power Case Study Monocrystalline Polycrystalline Solar Panels Bursa City, Turkey", International Journal of Photoenergy, pp. 17, 2016.

[6] O. Eseosa dan U. Roland, "Design and Simulation of Solar Monitoring Tracking System", IOSR Journal of Electrical and Electronics Engineering (IOSR-JEEE), e-ISSN: 22781676, Vol 4, issue 5, pp. 35-39, 2015.

[7] R. Şihab, Y. Öner, S. Gorgulu, dan B. Uslu, "Polycrystalline Photovoltaic Test Set Design", IOSR Journal of Electrical and Electronics Engineering (IOSR-JEEE) e-ISSN: 22781676, p-ISSN: 2320-3331, Vol. 13, Issue 1 ver.1, pp. 17-22, 2018.

[8] Y. Hailu, "Non-inverting Operational Amplifier," 2018. [Online]. Available: https://www.electronics-tutorials. ws/opamp/opamp_3.html. [Accessed: 26-Jul-2020].

[9] A. Faudin, "Tutorial Arduino Mengakses Modul RTC DS3231", Available on: https://www.nyebarilmu.com. 